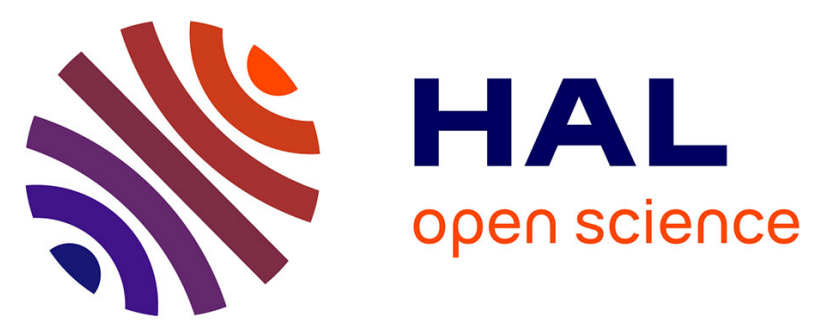

\title{
Singing the same tune? International continuities and discontinuities in how police talk about using force
}

P. A. J. Waddington, Otto Adang, David Baker, Christopher Birkbeck, Thomas Feltes, Luis Gerardo Gabaldón, Eduardo Paes Machado, Philip

Stenning

\section{To cite this version:}

P. A. J. Waddington, Otto Adang, David Baker, Christopher Birkbeck, Thomas Feltes, et al.. Singing the same tune? International continuities and discontinuities in how police talk about using force. Crime, Law and Social Change, 2008, 52 (2), pp.111-138. 10.1007/s10611-008-9176-7 . hal-00535458

\section{HAL Id: hal-00535458 \\ https://hal.science/hal-00535458}

Submitted on 11 Nov 2010

HAL is a multi-disciplinary open access archive for the deposit and dissemination of scientific research documents, whether they are published or not. The documents may come from teaching and research institutions in France or abroad, or from public or private research centers.
L'archive ouverte pluridisciplinaire HAL, est destinée au dépôt et à la diffusion de documents scientifiques de niveau recherche, publiés ou non, émanant des établissements d'enseignement et de recherche français ou étrangers, des laboratoires publics ou privés. 


\title{
Singing the same tune? International continuities and discontinuities in how police talk about using force
}

\author{
P. A. J. Waddington • Otto Adang • David Baker • \\ Christopher Birkbeck • Thomas Feltes • \\ Luis Gerardo Gabaldón • Eduardo Paes Machado • \\ Philip Stenning
}

Published online: 16 December 2008

(C) Springer Science + Business Media B.V. 2008

\begin{abstract}
This article focuses on a research project conducted in six jurisdictions: England, The Netherlands, Germany, Australia, Venezuela, and Brazil. These societies are very different ethnically, socially, politically, economically, historically and have wildly different levels of crime. Their policing arrangements also differ
\end{abstract}

P. A. J. Waddington $(\bowtie)$

History and Governance Research Institute, University of Wolverhampton, Room MC309,

Millennium City Building, Wulfruna Street, Wolverhampton WV1 1LY, UK

e-mail: P.A.J.Waddington@wlv.ac.uk

O. Adang

Netherlands Police Academy, De Kleiberg 15, 7312 SN Apeldoorn, Netherlands

e-mail: Otto.Adang@politieacademie.nl

O. Adang

Postbus 1201, 7301 BL Apeldoorn, Netherlands

D. Baker

School of Humanities, Communications and Social Sciences, Monash University, Gippsland Campus,

Churchill, Victoria 3842, Australia

e-mail: david.baker@arts.monash.edu.au

C. Birkbeck

School of English, Sociology, Politics and Contemporary History, University of Salford,

Crescent House, Salford M5 4WT, UK

e-mail: c.h.birkbeck@salford.ac.uk

T. Feltes

Criminal Justice Policy and Police Science, Ruhr-University Bochum,

Universitätsstraße 150, GC 5, 44801 Bochum, Germany

e-mail: thomas.feltes@rub.de

L. Gerardo Gabaldón

Instituto de Investigaciones Jurídicas, Universidad Católica Andrés Bello, Edificio de Postgrado, piso 2, Urbanización Montalbán, La Vega, Caracas, Venezuela

e-mail: luisgerardogabaldon@gmail.com 
significantly: how they are organised; how their officers are equipped and trained; what routine operating procedures they employ; whether they are armed; and much else besides. Most relevant for this research, they represent policing systems with wildly different levels of police shootings, Police in the two Latin American countries represented here have a justified reputation for the frequency with which they shoot people, whereas at the other extreme the police in England do not routinely carry firearms and rarely shoot anyone. To probe whether these differences are reflected in the way that officers talk about the use of force, police officers in these different jurisdictions were invited to discuss in focus groups a scenario in which police are thwarted in their attempt to arrest two youths (one of whom is a known local criminal) by the youths driving off with the police in pursuit, and concludes with the youths crashing their car and escaping in apparent possession of a gun, It might be expected that focus groups would prove starkly different, and indeed they were, but not in the way that might be expected. There was little difference in affirmation of normative and legal standards regarding the use of force. It was in how officers in different jurisdictions envisaged the circumstances in which the scenario took place that led Latin American officers to anticipate that they would shoot the suspects, whereas officers in the other jurisdictions had little expectation that they would open fire in the conditions as they imagined them to be.

\title{
Introduction
}

Although the articles in this special edition are not restricted to the international research collaboration that will be the focus of this contribution, they nonetheless all arose, in one way or another, from it. That collaboration saw scholars in six jurisdictions conduct research using essentially the same methodology, thus enabling direct comparisons to be made between societies, polities, jurisdictions, and cultures - a rarity in research on policing.

The reason for embarking on such a complex and difficult intellectual enterprise was to explore issues of paramount interest in police studies. Whether or not the police have a monopoly over the use of force, there is widespread agreement that the capacity (and indeed the duty) to use force as an instrument for the achievement of mandated goals is central to the police role. In all jurisdictions police routinely and openly carry weapons that are not readily available to the remainder of the population. It has become a commonplace of police research that whilst recourse to the use of force is relatively rare [1-3], the capacity to enforce compliance underwrites a great deal of what the police do. It also poses an acute ethical and

\author{
E. Paes Machado \\ Faculdade de Filosofia e Ciências Humanas, Universidade Federal da Bahía, \\ Salvador, Bahía CEP 40210-90, Brazil \\ e-mail: epm@ufba.br \\ P. Stenning \\ School of Sociology and Criminology, Keele University Keele, Staffordshire ST5 5BG, UK
}


constitutional issue, for this capacity to use force is easily open to abuse. It is instructive that authoritarian states earn the sobriquet 'police state' because it is the proverbial knock of the police in the middle of the night that epitomises rule by fear. As David Bayley long ago remarked and Paul Chevigny more recently reminded us: 'the police are to the state what the edge is to the knife' [4]. The six jurisdictions in which our research was conducted included those with reputations for civility and others which are now only emerging from authoritarianism. England was the birthplace of civil policing and has long enjoyed robust democracy; Holland has an enviable reputation for social and political tolerance; Germany has successfully awoken from its Nazi nightmare; Australia owes its origins to colonialism and whilst it has evolved into an independent democracy, still bares the scars of genocidal racism towards Aboriginal people. On the other hand, both Latin American countries have only recently emerged from dictatorships-Venezuela in 1958 and Brazil in 1985 - and remain plagued by political uncertainty and turmoil.

It is not 'the state' that knocks the door in the middle of night, but a police officer - a corporeal being - acting on its behalf. Whatever influence the state exerts is communicated through and mediated by the police who are its agents. Whether police officers do the state's bidding enthusiastically or reluctantly, facilitate or suborn the state's policies, depends to some extent upon how those officers think and feel about the tasks they are asked to perform. This raises the issue of police culture: the informal values, beliefs and norms that guide officers in their daily routine and produces the patterns that are observed in actual police practice, not least of which is officer's willingness to use force [5]. Police culture has been portrayed in much of the academic and policy-related literature as a malign influence: deeply conservative, prejudicial to minorities, action-obsessed, and tolerant to wrongdoing by fellow officers [6]. However, such a portrait emerges mainly from case studies within specific jurisdictions. How far do differences in police culture explain the considerable variance in the police use of force across different jurisdictions? By posing the same scenario to officers across diverse jurisdictions we hoped to find therein echoes of distinct police cultures, for if culture is such a powerful influence on the actual behaviour of officers then we would expect that officers from such divergent jurisdictions would talk about the use of force in different ways.

\section{Diverse national contexts}

Crucial to this research is the diversity of the jurisdictions in which the fieldwork was conducted. In this section we will explore that diversity.

\section{England and Wales}

England and Wales form a single jurisdiction within the UK and is commonly credited as the birthplace for modern professional civil policing. Today, England is economically stable thriving country of approximately 60 million people, which has become rapidly multicultural during the past 50 years.

Policing in England and Wales emerged from a patchwork of arrangements reflecting political expediency rather than any coherent plan. Until recently, 43 
police forces had more or less unitary responsibility for policing their respective areas, but in the last few years a national tier of policing has emerged and now coalesced into the Serious and Organised Crime Agency that amalgamates police, customs and immigration officers with personnel from other professional backgrounds, public and private, to fight crime on a transnational and national scale. An attempt to reduce the number of territorial police forces [7] was recently defeated, but police are encouraged to collaborate across borders in the interests of efficiency. This is symptomatic of a centralisation of political responsibility over the police that has grown markedly in recent years with national governments setting annual targets enforced by plethora of inspectorates.

The police, once an icon of British society, have become an increasingly controversial public institution during this same period and their popularity has declined markedly during the past 30 years [8]. They have been racked by scandals, especially regarding their relationship with ethnic minorities, whom they are accused of both 'overpolicing' and 'under-protecting' $[9,10]$. One expression of 'over-policing' that has caused repeated controversy has been the use of force. The once traditional unarmed British 'bobby' is now attired in body armour, and carries an assortment of weaponry: rigid handcuffs, batons openly displayed, and CS incapacitant spray. Most of the 43 police forces maintain 24 hour armed response vehicles able to attend any incident in which firearms have been used or are suspected as being present. Some of the larger police forces also maintain what amounts to heavily armed Special Weapons and Tactics teams for hostage rescue, anti-terrorist operations and other similar duties. As controversy increasingly engulfed policing so there has been a growth in civilian oversight, with a succession of organisations (each enjoying greater powers than its predecessors) having responsibility for investigating allegations of police wrongdoing. Currently, any occasion in which a person suffers serious injury or death as a result of police action must be referred to the Independent Police Complaints Commission who may (and in the case of death invariably does) conduct their own independent investigation. [11]

Police use of force is not explicitly justified under British legislation, for the relevant statute states that 'any person may use such force as is reasonable' for a lawful purpose such as preventing crime and apprehending offenders. However, police officers have duties and capacities that set them apart. Notably, police carry weapons that would otherwise be illegal. They are also subject to a variety of official guidelines on how to use force, such as the prohibition on using rigid handcuffs to achieve 'pain compliance'. The use of lethal force is only permitted when there is an immediate threat to life and sole responsibility rests with the officer employing that force.

\section{Netherlands}

The Netherlands enjoys similar levels of prosperity to those in the UK, and like Britain, the Netherlands is a geographically small coastal state with high population density. It has an imperial history with colonies in the Far East, Caribbean, Latin America and Africa. As migrants from its former colonies have settled into the Netherlands, it has become an increasingly multicultural society. This has tested the country's long established reputation as the epitome of a liberal political and cultural tradition, especially since the murder of the right-wing populist politician, Theo van Gogh by an Islamist militant. 
Policing in the Netherlands was traditionally based on municipalities but was reformed in 1990s into 25 regional forces, with an additional national force responsible for policing transport arteries, providing services to regional forces (for instance, forensic analysis) and performing such tasks as diplomatic protection. The police have dual accountability: on the one hand, they are responsible to the mayor of the municipalities in which they operate for public order and providing general assistance, but criminal investigation is the province of the public prosecutor.

Dutch police officers are routinely armed, each with a sidearm. As in Britain, the Dutch police must use force only with restraint to achieve a lawful purpose and they too are surrounded by a plethora of official guidance and instruction. Like British procedures, lethal force is allowed only in the most extreme circumstances, but unlike Britain (where the officer firing a gun is wholly responsible for doing so and there is no defence of obeying orders) firearms may be discharged upon the command of a senior officer and warning shots are prescribed. The use of force in the Netherlands is frequently a cause for public concern and there have been a series of controversial incidents in recent years.

\section{Germany}

Germany represents the continental tradition of the 'strong state' with a history of authoritarian rule that reached its malign pinnacle during the Nazi period from 1933 to the end of the Second World War in 1945. After the war Germany was divided into what emerged as an enormously prosperous liberal democratic Federal Republic in the west and communist dictatorship in the east. Partition ended in 1989 when the Berlin Wall was famously demolished and the following year the two parts of Germany were reunited into a single democratic federal state of over 80 million population. This has imposed economic strains, and whilst Germany continues to be prosperous, it has begun to suffer problems of unemployment, especially in the former communist east. Germany too is a multicultural society, with a noticeably large Turkish population and recent influx of asylum-seekers. In addition approximately four million people of ethnic German origin have repatriated to Germany from countries abroad in recent years.

After the Second World War the Federal Republic shrugged off its Napoleonic policing tradition in favour of a federal system in which each Lander (or state) has full responsibility for policing. With the assimilation of the former communist east, the federal system was extended throughout the entire country. Apart from responsibility for uniformed patrol and detective functions, each state has specialist squads who are trained and equipped to deal with emergencies, including riot and disaster management. Policing at the national level is the province of the Federal Crime Agency, which concentrates on offences against state security and international crime. It also provides services to the state police that are most efficiently delivered at national level, such as forensic analysis. Federal Border Guards are responsible for protecting the national borders and aviation security, and have become more prominent with the growth of transnational threats.

A distinguishing feature of German policing is its adherence to the 'principle of legality' that formally requires police officers to investigate all crimes that come to their attention. This denies German officers the legal latitude that is afforded to their 
English counterparts who are free to exercise their discretion about how to proceed with a breach of criminal law. As in the Netherlands, the police in Germany conduct criminal investigation under the direction of public prosecutors.

Like the Dutch, German police officers are routinely armed and all three European countries are bound by the European Convention on Human Rights that requires that use of lethal force must be necessary and proportionate. However, it is worth noting that in both the Netherlands and Germany it is permissible for police to fire at escaping suspects under limited circumstances, whereas no such option is offered to the British police. Any allegation of misuse of force is investigated internally in Germany and referred to the public prosecutor, there being no independent investigation or adjudication.

\section{Australia}

Modern Australia was colonised in the eighteenth century by British settlers and was a penal colony during this initial period. Today, Australia is an independent prosperous federal state of 21 million people. Since World War Two, it has forsaken its previous dependence on British immigrants and become a vibrant multicultural society, but strains continue to be felt in relations between Indigenous Australians - who suffer deprivation and discrimination - and the more prosperous settler population.

When the six component colonies coalesced into a Federation in 1901 they retained their state-wide police systems responsible for the full range of policing duties, as too does the Northern-Territory. In 1981 the Australian Federal Police (AFP) was formed with three principal functions: local policing of the Australian Capital Territory around the city of Canberra; national and international policing; and more recently (together with the Australian Security Intelligence Organisation) has a leading role in the 'war on terror'. In 1990 the AFP was restructured along the lines of an FBI. Whilst officers are routinely armed, state police maintain specialist units to deal with serious armed incidents and riot control.

The criminal law in Australia is a matter for each of the six states, with reserve powers vested in the federal level of government. Heightened security consciousness in Australia, as elsewhere, has been translated into politically controversial extended police powers and some transfer of policing and security functions to the federal authorities. In common with England and Wales the police are entitled to exercise discretion in how they fulfil their duty and inevitably it is street-level officers that do so most frequently.

Australian police forces trace their origins back to the civil traditions of Britain and in many isolated communities they performed the wide range of duties characteristic of 'community policing'. However, policing in Australia in the nineteenth century was also profoundly influenced by the militaristic colonial style of policing common throughout the British Empire. It is instructive that routine arming of police officers has been a relative recent innovation in all states (with New South Wales in 1970 being the first state to have armed operational police). The police in the more expansive though thinly populated states, especially on the goldfields and amongst mining communities, earned a reputation for heavy-handed suppression of labour unrest and abuse of Indigenous people was common.

Australian police formally avow commitment to 'community policing' and a 'service' ethic. Guidelines emphasise that only minimum force proportionate to the risk posed is permissible and priority is formally given to 'effective communication 
and conflict resolution'. In common with others, officers have recourse to an array of weapons, other than firearms, so that they can act proportionately in the face of violence. Since the mid-1980s Australian state police forces have become subject to civilian oversight of varying levels of rigour. There has also been a succession of highly visible public inquiries into police wrongdoing, especially in connection with the use of force, followed by more or less rigorous processes of reform. As in many other police forces, racism is perceived as common amongst lower ranking officers.

\section{Venezuela}

Venezuela is a former Latin American colony of Spain from whom it secured independence in 1821, becoming a sovereign state in 1830. It suffered from political autocracy until 1958, when a democratic government was installed. However, popular perceptions of economic mismanagement and corruption caused chronic political instability, and it experienced most recently two general strikes and a military coup in 2002, all of which failed. Throughout the twentieth century Venezuela benefited from the exploitation of rich oil and other mineral deposits that remain at the heart of its economy. However, like other Latin American countries it continues to suffer high levels of economic inequality and its major cities are notable for the 'barrios' that surround them in which an economically marginal section of the population scrapes a living. Although almost universally Spanish-speaking, Venezuela is ethnically mixed as the result of inter-breeding between Spanish colonizers, native tribal people, and slaves of African heritage. More recently, during the turmoil in Europe during the 1930s and 1940s there was large-scale immigration from the Iberian peninsula and southern Europe, and the oil boom in the 1980s prompted migration from Asia and the Middle East. Instabilities in the region have also added to immigration, especially from Colombia. Official homicide rates have risen precipitately in recent decades, fuelling widespread fear of crime and prompted vigilante actions, including the 'lynching' of suspected criminals.

Venezuela is a federal system, comprising 23 states. Executive power is vested in the President and Council of Ministers, whilst the judiciary (including public defenders) are headed by the Supreme Court. Its legal institutions are founded upon the European civil law tradition, exhibited for example in the codification of criminal offences. Radical amendments to the Code were introduced in 1999 replacing the inquisitorial with an adversary system and curbing police powers. Whilst it has subsequently been 'toughened up' by further amendments, police undoubtedly have fewer powers now than they had previously.

Policing follows the contours of government. The national government has five police forces: the Judicial Police responsible for criminal investigation accountable to public prosecutors; the Political Police is part of the Ministry of the Interior and deals with national security; the National Guard is attached to the Ministry of Defence and protects the national borders and a miscellany of internal responsibilities; the Traffic Police controls highways; and the Military Police is devoted to crimes such as rebellion and desertion. All 23 states and the Capital District possess their own police forces operating under state law, within the oversight of the Ministry of the Interior. Some of the larger municipalities also have their own police forces, but despite pretensions to the contrary, the major institutions of criminal 
justice (judicial police, courts, prisons) belong to the national government. Attempts have persistently been made since 1977 to simplify this abundance of overlapping jurisdictions, so far without success.

Venezuelan police are routinely equipped with firearms and batons, but only rarely with other less-lethal weapons. Equipment standards are poor with unsophisticated weapons and shortages of supply. Some police and all National Guard officers carry long barrelled firearms, in the latter case assault rifles. Rules for the use of force are very general, largely confined to firearms, varied between jurisdictions and relatively unimportant in officer training. Each police force has guidelines but they offer little specific guidance on how or when force is justified. Some guidelines use restrictive rhetoric (such as, force must be 'strictly necessary') but violations do not constitute a crime. The Criminal Code limits the use of firearms to self-defence and maintenance of public order, and improper use of the firearm could be a criminal offence. Parallels may be legitimately drawn with the law and official guidance regulating the use of force in the countries discussed above, but the defects of such generalities are reinforced by training regimes that emphasise technique (such as marksmanship) rather than instilling restraint. This is compounded by the virtual absence of refresher training and any record of those occasions on which force is used.

There is little accountability regarding the use of force by police officers. Citizens may complain, but unless complainants are members of the 'respectable' sections of the population, they are unlikely to be recorded, still less investigated or adjudicated. 'Shoot-outs' between police and alleged criminals are commonly reported in the press, but excite little attention. Human rights activists estimate that in a 12 month period there were 435 civilian deaths in shoot-outs reported in the national press. In addition, there are strong suspicions that police participate in 'death squads'. The Human Rights Ombudsman estimates that 379 homicides during 2003 were suspected extra-judicial executions. Yet, despite official reports drawing attention to the issue, little political action has followed except on those occasions when 'respectable' citizens are directly involved. Whilst such activities are not entirely unknown amongst the countries discussed previously, the scale and normalisation of such killings sets Venezuela and its neighbour, Brazil, apart.

\section{Brazil}

Brazil is the last jurisdiction amongst the array represented in this research. It is the country with the largest territorial area in Latin America and has a racially and culturally very mixed population of 190 million residing mainly on the Atlantic coastal strip. It was colonized by Portugal in the sixteenth century, achieved independence in 1822 followed by a protracted period of political instability and military coups. It is now a democratic federal republic comprising 26 states. Brazil survived a severe financial crisis in the 1990s and is now one of the world's largest and fastest growing economies, and is self-sufficient in energy. Like Venezuela, there are considerable inequalities and poverty is concentrated in the favelas (shanty towns) on the edge of large cities that have become notorious as citadels of crime organised by well-armed and ruthless gangs. Crime rates, and especially violence and kidnapping, are high (UNESCO reported 40,000 firearms fatalities in 2007 alone). Prosperous classes increasingly isolate themselves in walled communities patrolled by private 
security firms. Less prosperous sections of the population are inclined to resort to vigilantism, administering beatings and sometimes killing those they suspect of crime.

Legal institutions reflect the civil law traditions of continental Europe, with a codified system of criminal law. Unusually, jurisdiction is not only defined territorially, but also through specialised military, labour and electoral courts, all presided over by the Supreme Federal Tribunal.

The principal police agency is the Military Police that is constitutionally aligned with the military, but under the control of each state's governor. However, policing in Brazil bears the scars of its birth as a colonial gendarmerie preoccupied by the necessity of repressing by overt coercion incipient revolt amongst the large population of slaves. This tradition was reinforced during the Cold War period when a series of military juntas were in power and police received instruction from US advisors on counter-insurgency strategy and tactics. The death squads that have made the Brazilian police so infamous were a by-product of this counter-insurgency emphasis but targeted at gangsters, suspected petty criminals, and even children living on the streets. Despite shedding military rule, the political influence of the police remains (fuelled, no doubt, by widespread fear of crime) so that the institution has successfully resisted reform.

In addition to the Military Police is a much smaller Federal Police that falls under the responsibility of the Justice Department with responsibility for combating drug trafficking, weapons smuggling, and money laundering. It too has been implicated in the worst excesses of policing in recent years. The Civil Police have general policing functions, but unlike the Military Police they have no accountability to the federal government and no allegiance to the armed forces, but instead are solely responsible to the Governor of the state and subservient to the political purposes of their master. Big cities also have their own Municipal Guards under the direction and control of the mayor. There are also administrative police forces, whose main operational focus is in regulating traffic and who have an unsavoury reputation for oppressing street vendors. With other policing agencies too numerous to itemise, the total police establishment approaches half a million officers. These arrangements succeed in creating fragmentation, internal competition and inefficiencies.

Police use of force is nominally governed by the Penal Code that outlaws disproportionate and excessive recourse to force. However, the police hierarchy, judiciary and general public are tolerant of excessive police violence provided it is directed at marginal sections of the population. Despite enacting laws against torture, abuse of those in custody remains commonplace. Police Board Reviews are internal accountability structures that are almost wholly ineffectual, serving to shield errant officers from the full rigours of the Penal Code. Ombudsmen, Parliamentary Commissions of Inquiry, and Human Rights Commissions have proved slightly more effective mechanisms of accountability, exposing and denouncing abuses, but are hobbled by insufficient resources and intimidated by the threat of retaliatory violence from accused officers. They must also endeavour to get their voices heard above the clamour of the popular press and mass media for more vigorous anti-crime measures that pay little or no heed to human rights.

Internal discipline within police forces is characterised by a militaristic structure and culture. However, bureaucratic inefficiencies leave most police officers with only meagre training, especially in the police use of force. Little attention is paid to 
using alternative methods of dispute resolution or exercising restraint in the use of force. On the streets, the levels of admitted killings by police officers is truly astounding, especially in Sao Paulo where in 1992 killings reached 1,482 during that year and whilst reduced subsequently never fell below 300 annually. The victims of these killings are overwhelmingly poor non-white male juveniles. Apart from these 'on duty' killings, police officers are responsible for a significant number of killings whilst 'moonlighting' as security guards.

It is apparent that the six jurisdictions in which focus groups were held spanned an enormous variety of historical, social, cultural, legal, and organisational conditions. Police organisations and officers are not autonomous: they exist within a particular set of such conditions which are frequently invoked as explanations for how policing is delivered on the street. In Britain explanations for the restraint with which force is employed are found in the culture of deference, the doctrine of 'policing by consent' and the fact that police are not routinely armed. By contrast, it is the colonial origins of policing in Australia that are often held responsible for contemporary strained relationships between the police and Aborigines. The authoritarian policing of grossly unequal Latin American societies is often thought to account for torture and the presence of 'death squads'. If so, then we can confidently anticipate that these differences will be detected in focus group evaluations of police conduct depicted in the scenario that remained a more or less common point of reference for all those who participated in this research.

\section{Talking about the scenario}

Groups of officers in these widely varying jurisdictions were presented with a scenario that was largely the same, but customised to fit local conditions. It consisted of three stages: first, two patrol officers see a vehicle with darkened windows, causing a traffic obstruction, and when one of them approaches he or she detects the odour of cannabis and the occupants are abusive towards this officer. He or she identifies one of the occupants as a known local petty criminal and soon afterwards the car drives away at speed. Secondly, the patrol car pursues the escaping vehicle at speed until the latter crashes. Thirdly, the two occupants jump out of the vehicle and run off, one of them in possession of what appears to be a gun, which he brings into the aim and fires. After each stage was read to focus groups, they were invited to discuss and evaluate the actions of the officers depicted in the scenario, and envisage what might happen subsequently. This section of the article will summarise those discussions, stage-bystage, but before we do let us acknowledge one important feature of those discussions that was universal: that is, the absence of complete agreement. At each stage there were divergent and even discordant voices amongst our focus groups, which in the course of being summarised might become unavoidably muted.

\section{Stage 1: Initial contact}

What was universally agreed by all participants was that the encounter described in the scenario- a couple of young men from a marginal section of the population, at least one 
of whom is known to the police, found in circumstances that attract the attention of the police and upon closer inspection are suspected of drug use - is utterly routine. English officers laughingly referred to it as 'business as usual'. In the view of all focus groups there was ample legal justification for approaching the vehicle and once the cannabis smoke was detected by the officer there is no legal impediment to arrest.

Some officers advised caution in approaching the vehicle depending on the general circumstances. Unarmed English officers ${ }^{1}$ were attentive to the description of the location as a 'rough' part of town and the time as dusk on a summer's evening. They said that they would pay attention to who was in the vicinity and whether they might become embroiled in a confrontation with a group. For instance, if the car was parked near a café in which young people from ethnic minority backgrounds congregated, then they might not bother to take any action because it might incur too much risk in return for insufficient benefit. However, it should be noted that officers who crewed Armed Response Vehicles shared no such inhibitions. 'They know us. They know our cars. They know not to mess with us!', was the view of one such officer. Australian officers also felt from the outset that this situation should be approached warily: 'They're not going to want the police. They're going to resist.' For Australians the hypothetical car's blackened windows represented a threat: "you don't know who you are dealing with." They felt it prudent to call the control room to "get more info on the car, some background on the car... you may have a reasonable amount of background knowledge on the car." Some officers advised touching the car's windows or paintwork so as to leave a fingerprint that would identify it later, should it drive off or further offences be committed. Officers in Germany expressed similar reservations, but concern was more muted than their unarmed English or armed Australian counterparts, whereas Dutch officers were initially more phlegmatic, treating the scenario as very mundane.

In both Latin American jurisdictions caution and wariness were elevated to a far higher level, because of the pervasively high level violence. In Venezuela, whilst the situation was considered not only routine, but a legally petty infraction that was unlikely to merit prosecution, it was also fraught with danger- the street is a hostile environment for the police: "When you engage in such a procedure, people from the shanties start throwing rocks and bottles." The occupants of the car were also defined as dangerous from the outset: "while approaching the car they [the officers] could be shot at"; "you don't know what they have in the car"; "the car can move and run over the officer." They favoured approaching the vehicle cautiously, keeping apart to prevent simultaneous attack; stressing the suspiciousness every officer should have in everyday routines, the need to be "suspicious" or "wary" about the risk of the youths using firearms. One view was that the officers should not approach the car on foot, but should give directions via the patrol car's loudspeaker to the occupants of the suspect car to alight from it with their hands up. All Venezuelan focus groups shared a fear of imminent attack: "We stop them, they are suspects, we verify for whatever. You have to follow your 'nose', as they say; everyone is armed and could hurt you, because it has happened many times: you stop them for running a red light, you don't suspect anything, the guy has just committed a robbery and he is armed, and when you approach him... well there have been a lot of officers killed

\footnotetext{
${ }^{1}$ The English focus groups comprised two groups of unarmed officers, and two groups of routinely armed crews of Armed Response Vehicles.
} 
that way." In Brazil some officers equated poverty and criminality: poor neighbourhoods have lots of criminals and are therefore more dangerous to work in. Hence police have to be more 'energetic' in low income neighbourhoods. Dusk makes things more difficult and risky because it is less clear who the police are dealing with. In the face of such risks the police culture of "maximum suspicion" encourages officers to conjecture about potentially negative possibilities, such as suspects carrying firearms, or involved in drug trafficking, or having a hostage in the trunk of the car - a view that prescribes the utmost caution.

Whether as a routine operating procedure or because of the potential for danger, focus groups in all six countries agreed that the control room should be notified at some early stage in the initial encounter. English officers envisaged the driver of the police car routinely asking for the registration number to be checked whilst his colleague approached the car, as did their counterparts in the Netherlands, Germany and Australia. As the scenario developed with evidence of drug-use and the abusive reaction of the car's occupants, focus groups agreed that back-up would be requested. Australian officers drew a distinction between rural and urban environments, for in the former 'back-up' might be some distance away and, therefore, should be summoned earlier, rather than later, whereas in towns one might expect back-up to arrive speedily. All of this testifies powerfully to a common feeling of vulnerability. English officers felt the least vulnerable (and armed officers exhibited few concerns about their vulnerability at this stage), but even though all focus groups agreed that this was a 'routine' encounter, it was still one redolent with risk.

The waft of cannabis smoke from within the car, the abuse from its occupants and the fact that one of them was known as a local criminal was universally treated as grounds for heightened suspicion. Abuse was dismissed by English officers - "it goes with the territory" was a frequently voiced response. Australians too felt it best to disregard abuse and obscenities. In the Netherlands and Germany there was an emphasis on remaining cool and calm in the face of such provocation and avoiding needless escalation. Whilst focus groups in both Latin American countries agreed with the need to remain calm, abuse was viewed more seriously as displaying lack of respect for the police, especially in Brazil. "If you are going to approach someone and you perceive them to be calm, to be speaking calmly, you are likewise going to act calmly; but if you see them to be agitated, you are also going to be agitated."

Abuse and evidence of petty illegality immediately placed the occupants of the car into the category of 'disreputable'. However, the connotations of that classification were most pronounced in the Latin American context. In Brazil, it was said that "a criminal cannot be treated as a citizen; the police treat citizens as they should be treated" and "...unfortunately, there are a lot of 'marginals'. So how is the officer going to know that the man is a citizen?"

Amongst European and Australian focus groups there was a large measure of agreement that the use of force should be avoided, however there was disagreement within all four jurisdictions about when the situation had deteriorated to the point where force would become justified. The aim was to get the occupants out of the car and the keys out of the ignition. In the Netherlands considerable emphasis was given to persuading verbally the occupants to comply, if at all possible. Officers would "Have a chat" with the occupants, remain amicable and only use powers if necessary- "it's the tone that makes the music", they said. 
Where police favoured approaching the car, it was to the driver's side that they would go and most would open the car door rather than await the window being lowered by the occupants. Only unarmed English officers failed to mention this: they saw nothing unproblematic about talking to the occupants through an open window. Their armed counterparts, by contrast, would open the car door and felt that as soon as there was evidence of cannabis smoke, abuse and recognition of a minor criminal they would grab the ignition keys and ask the occupants to alight. Failure to comply would result in the driver being "dumped on the ground". German officers took much the same view: it would be preferable to gain compliance by request, but disrespect would prompt firm action. German officers expressed the view that it was imperative to maintain respect and that once there was resistance it should be overcome assertively. This was not a view shared by all focus group participants in the Netherlands where some officers felt that such an intervention would escalate the situation: "Over here we do not do things like that", whereas others took the same view as some of the focus groups in other countries that greater assertiveness was appropriate: "My way or highway" - that is, get out of the car or be dragged out. In Australia too there was some debate about whether refusal to alight from the car would prompt immediate arrest or less forceful action.

In Venezuela, focus groups also stressed the need to be polite, but once there was evidence of criminality and resistance forceful action would swiftly follow:

We are dealing with two people we know; they have a police record; the car is probably stolen and they are adopting an aggressive attitude toward us... we try every way get the guys out of the car, including blocking it off, but sometimes they refuse to obey, arguing that they are the brother of the president of whatever, and I have no right to pull them out of the car... but these guys, you know, they are "two jewels" [a mocking expression meaning two punks].

Brazilian focus groups felt that they would unholster their firearm as they approached vehicle, but also preferred to issue commands. They were alone in being incredulous that the occupants of the car would not comply. On the other hand, they would remain vigilant, insisting at all times that they could see the occupant's hands.

In sum, there are distinct similarities in how police in the various jurisdictions consider it appropriate to act in the circumstances described in the scenario. First, whilst a routine encounter, officers are wary: they all agree that they would inform the control room of their location and begin a routine vehicle check; once they met any resistance they would ask for back-up and if the environment was hostile or isolated they might do so in any case as a precaution. However, the degree of that wariness varied enormously: in Europe and Australia officers were attentive to their safety and the possibility that the encounter might reveal something serious or spiral out of control, but in Venezeula and Brazil there was much greater perceived danger. That danger lurked in the potential criminality of the car's occupants - they may be armed - and the reaction of residents in the neighbourhood - who might throw rocks at the police. Secondly, all focus groups stereotyped the young men as potentially threatening 'problems' and often described them as 'scumbags', 'low-life', 'jewels', or 'punks', certainly not 'citizens' deserving respect. Thirdly, all focus groups shared the view that it was imperative that they maintain control, but that control extended to controlling their own reactions to the abuse received from the occupants of the 
car. Most of them favoured getting the occupants out of the car and key out of the ignition. Fourthly, focus groups agreed that the preferred option was to achieve this by oral means, but if the occupants failed to comply there was a large measure of agreement that force would be used.

\section{Stage 2: Car chase}

In the second stage of the scenario, the car suddenly drives off. This was regarded by most officers as the predictable consequence of the failure effectively to control Stage 1. Venezuelan officers even used terms like 'police misconduct' to describe it and saw the remaining scenario stages as confirmation that Stage 1 had been handled badly.

Given that this contingency had arisen there was remarkable agreement across all jurisdictions of the obligation on the part of the police to balance public safety against arresting the car's occupants. In England this led to three views: first, that pursuit was not worth the risk and that the occupants of the car would 'come again,' that is come to the attention of police in future in connection with offences. Secondly, was the view that the officers would commence pursuit of the escaping vehicle but would be ordered to desist once they informed the control room. Thirdly, some focus group participants thought that officers would, at least, be tempted to delay informing the control room or dissimulate in order to continue a pursuit that would otherwise be called off. In the Netherlands there was a similar debate between those who felt the imperative to "get these guys," whilst others took a more cautious approach: there was insufficient reason to pursue and it would expose other road users to unjustifiable risk of harm.

In Germany and Australia there was greater agreement that the car would be pursued, albeit with caution for fear of exposing other road-users to danger. Here they articulated more consensually the minority view in England that the 'hunting instinct' (as German focus groups referred to it) would prove irresistible. They acknowledged that the legal justification for pursuit was slender, but pointed to the emotional, adrenalin-fuelled, desire for the police not to suffer humiliation. In Australia it was seen as equally "natural" to pursue those who flee from the police, for it was necessary to "draw a line in the sand." However, here too they expected to receive an instruction to desist from the pursuit once the control room was informed. Once the pursuit had commenced there was also agreement that it was necessary to mobilise further resources to bring it to a safe conclusion. In England, the scenario envisaged that an Armed Response Vehicle was in the vicinity and joined the chase, but this was regarded as so unlikely as to be fanciful by the focus groups composed of unarmed and armed officers alike. So too, was the possibility of air support in the form of a helicopter.

These same concerns were no less important for the Brazilian focus groups and again there was no consensus. They too were attentive to the danger to bystanders, the likelihood that they would be ordered to cease the pursuit, and the risk of being held responsible for any misfortune that might arise: "in those circumstances, you're in danger of getting reprimanded; you crash the car and you have to pay the damages, you risk being put on trial." There was also the danger to the officers themselves: "you can die because you're after a vagabond." Here too there was 
recognition of the primal urge to pursue those who flee; an urge that should be resisted: "We don't want to be a hero or to act like a wild animal, right?"

Very similar considerations were voiced by Venezuelan focus groups. Participants felt the same temptation to pursue those who flee: "You have to live the experience. It's something unplanned. Your adrenaline gets high." They too used the imagery of hunting: "Like a tiger that hunts a deer." On the other hand, they also felt the need to balance this instinct against the dangers to bystanders and the restraining hand of official policy that would probably order cessation of the chase. If there was to be a collision, even if it only involved the police car, the pursuing officers might find themselves held responsible. However, ambiguities in official policy did allow some room for manoeuvre that officers in these circumstances might exploit to justify the chase.

In Germany and Venezuela focus group participants raised the prospect of using greater force to terminate the chase, but did so to rule out these options. German officers expressly ruled out either ramming or shooting at the car, because of the danger than an uncontrolled collision would have for innocent bystanders. Venezuelan officers also debated whether it was legitimate to open fire on the escaping duo, but the majority dismissed it as an inappropriate response.

In all jurisdictions it was felt that official policies that restricted the capacity of patrol officers to pursue fleeing vehicles were unrealistic (because of the imperatives of the 'hunting instinct') and inappropriate (because it impeded the enforcement of the law and allowed suspects to escape justice).

\section{Stage 3: Armed threat}

In the scenario it is envisaged that the pursued car is involved in a collision, that the occupants decamp and run off, and that one of them is perceived to be in possession of a firearm that is, after a short while, aimed at the police and then fired. Perhaps unsurprisingly, it was this stage that evoked the most intense debate in all jurisdictions. The terms of that debate were remarkably similar: prudence of giving chase on foot; danger to bystanders; justification for opening fire; alternative tactics in the situation.

In England the scenario was modified to contrive the availability of armed officers at the scene of collision. There was a striking difference of opinion between focus groups composed of armed and unarmed officers about how the armed officers depicted in the scenario would and should deal with the situation as described. Hitherto, the focus groups composed of armed officers had been noticeably more assertive in their approach to the scenario: they entertained no hesitation in approaching the vehicle when it was obstructing the highway and would have acted assertively once they detected cannabis smoke; they also imagined that as qualified pursuit drivers they would be permitted to chase the escaping car. Unarmed officers, by contrast, were more wary and thought it less likely that they would be allowed to pursue the vehicle. Once the car had crashed and the occupants decamped, with one of them apparently in possession of gun, the balance of opinion was reversed. Now, it was armed officers who became wary and cautious, whilst their unarmed colleagues expected an armed confrontation in which shots may well be fired.

English officers had to envisage a process that did not apply elsewhere, for even the crews of Armed Response Vehicles (at least in this force area) were not routinely 
armed, but instead were required to obtain authority from a senior officer before taking weapons from the armoury on-board the vehicle. Focus groups of armed officers did not share the belief of their unarmed colleagues that they would receive that authorisation, or indeed that upon seeing what apparently was a gun in the hand of one of the escaping duo, that this would provide sufficient legal justification for authorising themselves to be armed because of the imminent threat. Their view was that there was insufficient legal justification: in the scenario intelligence reports linked the vehicle with a drugs-related shooting, but armed officers viewed that with the utmost scepticism. What does 'involvement' entail, they asked? The vehicle may simply have been in the vicinity of the shooting at the same time, which they felt was hardly surprising given its current occupants and their apparent lifestyle- "These are not nice people" the officers pointed out. From what source does this 'intelligence' come? It could just be gossip or mischievous: "For all I know, it could have been some bollocks told to a detective by a snout" (that is, unreliable information provided by an informant). 'Errol King' is known to police and either or both of the car's occupants appear to have been consuming cannabis, but that (armed officers were anxious to point out) was not a threat to life. One of the occupants appears to be in possession of a gun, but armed officers emphasised that it was 'appearance' rather than reasonable certainty. The question that armed officers asked rhetorically and repeatedly was "What have we got?" and the answer was repeatedly that there was nothing sufficiently substantial to justify arming themselves.

Even when armed officers were invited to imagine that they had been authorised to arm themselves, they continued to express the utmost caution. They pointed out that it takes time to open the armoury on-board the vehicle, extract the weapons, load them, and don body armour; by which time they anticipated that the escapees would have disappeared from sight. If, by some extraordinary circumstances either or both of the duo remained in view, officers would be reticent about giving chase. First, they pointed to the need to preserve the scene of the collision. If the car was in some significant way 'involved' in a drugs-related shooting, then it would need to remain secured for forensic analysis. Secondly, even if one of the escaping duo was in possession of gun, that did not necessarily mean that it was the only gun they had and that no other firearms had been left in the abandoned vehicle. To set off in pursuit of the escapees might leave a lethal threat inside the car. Thirdly, crews of Armed Response Vehicles do not patrol the same locality habitually, so they are likely to be unfamiliar with the area, unlike those who they would be pursuing. The danger, therefore, is that if there is anything incriminating in the wrecked vehicle, its occupants might return and, if armed, would pose a threat to the unarmed officers at the scene. Fourthly, a foot pursuit of two escapees would be inherently dangerous. "I'm not running around a corner into who-knows-what", said one focus group participant. "What if the two of them split up?" asked another rhetorically. It would be imprudent for each of the officers to pursue their quarry separately, because officers are deployed in pairs each to guard the other and with two armed officers in an area with which they were unfamiliar they might lose contact and then later cross each other's path with the danger of a 'blue-on-blue' shooting.

Tempted again to consider the possibility that one of the escaping duo turns and aims what is plainly a firearm in the direction of officers, focus groups of armed officers still maintained their cautious approach. In such circumstances there would 
be ample legal justification for them opening fire upon their adversary, but other considerations intruded. It would be necessary for them to consider the 'backdrop': in other words, the situation around the armed man and in the arc of fire beyond where any bullet fired by police might continue its trajectory or, even more unpredictably, ricochet. The scenario indicates that it is a populated area: there might be innocent bystanders who would be endangered by any exchange of fire, especially from any appreciable distance. "If I fire a shot at an escaping scumbag and miss, it could hit a mother pushing a pram."

Armed officers were unanimous: they would remain with the wrecked vehicle, summon a helicopter, additional armed officers, and conduct a methodical search of the area using police dogs. Thus, in stark contrast to a foot chase by armed officers, followed by a confrontation and shots fired, envisaged by focus groups composed of unarmed officers, their armed colleagues exhibited considerable caution.

The caution exhibited by focus groups of armed officers, may be thought to be a reflection of the unarmed tradition of policing in Britain. After all, in all the other jurisdictions represented in this research, officers are routinely armed. There would be no requirement to obtain authority to arm themselves and delay in doing so. Would they more readily give chase? Would they open fire if confronted? First, it is important to appreciate that the scenario depicts circumstances that are extraordinary, certainly for the European and Australian police. As officers in Germany were at pains to point out, once the scenario reached Stage 3 it rapidly exceeded their experience and became hypothetical. Nevertheless, the same caution was evident not only amongst European and Australian officers, but also (with some qualifications) amongst their Latin American counterparts. Dutch officers would not routinely draw their handgun to approach the vehicle after the collision, nor to pursue the erstwhile occupants of the car as they escaped. If the escapees were clearly in possession of a gun, the officers envisaged unholstering their own, but they were acutely aware of the presence of bystanders. Some officers questioned the scenario because it involved operating "untactically." Likewise, German officers thought that the correct thing to do was to attend to any innocent bystanders hurt in the collision with the escaping vehicle. However, it was recognised that the 'hunting instinct' might take over. Even so, there was debate and disagreement about whether it was appropriate to unholster one's own firearm; instead, it was considered better to keep the escapees in view from a distance. The danger of the escapees finding themselves trapped and being faced with the prospect of 'standing and fighting' was something to be avoided and opening fire was seen as wholly exceptional and only conceivable as a very last resort, not least because focus group participants were acutely aware of the limitations of their own marksmanship and their weaponry.

Australian officers agreed that the first priority following the collision would be to attend to any innocent bystander who had been injured. The first preference would be to contain and control the escapees and their car, possibly by blocking it in with their own vehicles. If the occupants escaped they advocated giving descriptions to the control room, mobilising specialist armed officers, police dogs and a helicopter, and warning bystanders in the vicinity that armed criminals were at large. Given that they knew the identity of one of the escaped occupants they saw no justification in taking risks to arrest either of them. However, like their German counterparts they accepted that the 'hunting instinct' might tempt them into giving chase, in which 
case they agreed with Dutch officers that they would follow at a distance. If the escapees disappeared into a shopping mall, officers would not follow them for fear of provoking panic amongst shoppers and an armed confrontation in a crowded environment. Instead, they would enlist the support of CCTV to follow the escapees within the mall, whilst they would cover the exits from outside. Their approach was summarised as one of playing for time: "Plenty of time, don't have to rush, take your time, and the end result is that nobody gets hurt;" "take it at our pace, not their pace; it's a police thing to catch the crooks straight away, but sometimes you have to sit back and take your time." There is time to plan, time to enlist other units. As one officer put it: "Get every bloody unit there from Christendom."

Here there is a gulf between the European and Australian focus groups, on the one hand, and those in Latin America, on the other. Venezuelan focus groups favoured immediately unholstering their handgun once the pursued car comes to rest after the collision, because: "We don't know if they are armed or not, and they can shoot at us... so, first us, our safety;" "or they are waiting for us to approach them so that they can shoot at us;" "these people aren't hurt, they get out firing at the officers, so we must be alert to an exchange of shots in such a situation;" "they could even open a window and throw a grenade at us." At the same time, officers are acutely aware of their legally precarious situation: "using the gun requires several steps, such as putting your hand on it, grabbing it, unholstering, aiming, putting your finger on the trigger and shooting, all of which are steps that are evaluated by the prosecutor and the judge. So you will have the gun on hand just for prevention, in case after the crash the suspects are not hurt and get out of the car firing at the officer."

The Venezuelan version of the scenario envisages the occupants of the car emerging with gun in hand and running off, firing at officers as they go. The fact that the escaping occupants of the car have opened fire upon pursuing police officers justifies police firing in return on grounds of self-defence. The "golden rule" seems to be that the suspect fired first, or at least (but not so good) that he was on the point of doing so. Shooting someone in the back is difficult to justify in these terms and therefore is imprudent because of the likelihood of disciplinary or legal repercussions. Many comments referred to the subsequent reconstruction of suspicious facts, such as the position of the corpse at the scene. Officers frequently said that they have to justify self defence at a trial, and the fact that many incidents end with the death of the civilians "is not because of the mere fact of their being armed, because you have not yet justified your action, but because our shots are precise." Whilst initially officers might have sought to arrest the occupants of the car, once the firing begins killing them is regarded as inevitable. "If he is armed and exchanges fire with the police, he would end up dead;" "This guy is already dead;" "this guy is luncheon meat."

Members of the Venezuelan focus groups were attentive to the danger posed to innocent bystanders in any exchange of fire. They agreed with common police practice in other jurisdictions that forbids the firing of 'warning shots.' Like their European and Australian counterparts they were concerned about the prospect of accidentally hitting the archetypal innocent bystander, for instance "What if someone is hanging the clothes out to dry?" They felt vulnerable to accusations that they have acted carelessly in such circumstances. However, rather than deterring officers from becoming involved in a violent confrontation, this concern prescribes the firing of 'safe shots' - that is, well aimed shots at the torso of the adversary. 
Much the same applies in Brazil: the legal justification upon which officers rest their actions is self-defence and like their Venezuelan counterparts they seek to avoid harming bystanders by the accuracy of their marksmanship. This poses problems because officers feel that they are ill-trained: "imagine... a police officer who is not prepared psychologically and technically... the "marginal" [suspect] runs right over them; you understand?" To remedy this, some officers pay for additional firearms training and ammunition with which to practice.

In sum, despite Latin American focus groups being presented with a more confrontational version of the scenario that invites the option of police returning fire, the members of these groups imagine doing so with considerable trepidation: fearing that their shots might hit innocent bystanders and having to justify their actions to a sceptical judiciary.

\section{Discussion}

What is so striking is that in jurisdictions that in so many respects are so very diverse, police talk about the use of force in such similar ways.

It is helpful to briefly set out the continuities and discontinuities. There was nearuniversal agreement that: the scenario depicted a routine encounter and yet risk and danger were present, although the perceived extent of such danger varied enormously; the young men in the car were viewed with complete distain and yet it was important for officers in such situations to remain cool and calm, especially in the face of abuse; the imperative to assert control was uppermost in the minds of police officers; the 'hunting instinct' might instigate risky behaviour, such as chasing the escaping car; control rooms would probably order the cessation of a car chase; official policies that prescribed cessation of the chase inappropriately favoured 'the bad guys' and were impotent (the 'hunting instinct' would prevail); safeguarding bystanders was a priority throughout; law on the use of lethal force was restrictive and could only be justified by an immediate threat to life. Systematic disagreements were restricted to whether or not to: unholster one's firearm immediately; give chase and, if so, how closely; and open fire on the fleeing suspects.

Could this be an artefact of the method employed? We consider this to be unlikely. To mitigate the effect of social desirability, this research made clear throughout that its focus was upon how officers evaluated and justified action in such a setting. Nevertheless, members of focus groups openly acknowledged the extent to which the 'hunting instinct' might encourage officers to breach rules, and voiced their opposition of restrictions such as those governing vehicle pursuits. Most importantly, it was our collective experience that focus groups engaged very deeply with the scenario and officers argued volubly over competing courses of action. This was captured most starkly in the differences between focus groups of unarmed and armed English police officers. In short, our focus groups echoed no simple consensus. Hence, our confidence that what our focus groups reveal are how officers in these jurisdictions justify, evaluate and explain police conduct.

European and Australia focus groups diverged from their Latin American counterparts at the most perilous moments in the scenario, especially giving chase to suspected armed criminals and willingness to open fire. This is congruent with 
reality: as was seen earlier, there is a vast gulf between European and Australian police and those in Latin America in the number of people they shoot and kill. So, this difference in talk and expectation should not be dismissed as merely hypothetical. Moreover, the scenario and focus group methodology proved to be sensitive to differences of approach amongst English focus groups composed of armed and unarmed officers, for they diverged markedly in directions that are counter-intuitive: the armed officers being more cautious than their unarmed colleagues when presented with the potential of an armed confrontation in the scenario.

What might we extract from our focus groups that sheds light on the difference between English, Dutch, German and Australian officers, on the one hand, and their Latin American counterparts, on the other? First, we must note the clear normative continuity between all the focus groups and the jurisdictions they represent. In many discussions of police use and abuse of force in Latin America emphasis is placed on how the police are inadequately regulated $[12,13]$. Legal institutions are depicted as impotent and public opinion, filtered through the mass media and political institutions, is thought to encourage police violence [14]. All this may well be true, but our focus groups gave little indication that officers felt able to shoot suspects with impunity. On the contrary, Latin American officers referred to how judicial investigation would interrogate each movement in grasping, drawing, aiming, fingering the trigger and firing their gun. They felt compelled not to shoot a suspect in the back and emphasised that opening fire was justified only in self-defence. They pointed to how the position of any corpse would be examined at the scene for incriminating evidence of unjustified shooting. This might lack the rigour of a 5-year long investigation and trial, such as that to which two English officers were exposed when they shot and killed a man wrongly thought to be in possession of a shotgun, which turned out to be a table leg, but equally Latin American officers did not appear to believe that they had carte blanche to kill.

Why, then, did they regard opening fire as virtually inevitable? The answer was that they perceived that they faced a hugely greater level of threat throughout the encounter. In Europe and Australia, in so far as officers perceived there to be risk and danger in approaching the car, it lay in the car driving off or the possibility that in this 'rough part of town' associates of the occupants of the vehicle might become obstructive. So, in England the expectation was that the patrol car driver would remain in the vehicle with the engine running, whilst checks were conducted on the suspects' car. The driver's companion meanwhile would approach the driver's door and open it. In the Netherlands emphasis was given to talking to the occupants and persuading them to alight from the vehicle and avoid needless escalation. Once resistance and abuse was experienced a more forceful response was to remove the ignition key and pull the driver from his seat.

This is markedly different from a near-identical scenario in Venezuela or Brazil. Here, the police saw themselves as facing the prospect that they would have been physically assaulted by other residents if they alighted from their patrol car. They feared from the outset that the occupants of the car were armed. Some wondered whether they might not prove to be kidnappers with a hostage in the trunk of the car. The perceived danger was such that some officers advocated hailing the car's occupants over the loudspeaker and inviting them to alight with their hands up. 
When the pursued car collided and came to rest, officers already feared that the occupants would emerge guns in hand and ready to shoot, or wait until police approached and then open fire. Whilst Latin American officers regarded the prospect of armed criminals firing their guns 'over the shoulder', their counterparts in the other jurisdictions regarded the armed encounter as an exceptional turn of events. German focus groups found this utterly beyond their experience. Not even the armed officers in England had fired their weapons operationally. In Australia, the scenario was so exceptional that it justified mobilising "every bloody unit... from Christendom".

\section{Disposition or situation?}

This distinction in the situation in which officers envisaged the scenario taking place and its impact on what they expected would happen resonates with the longstanding debate within academic circles about whether it is the disposition of officers or situational factors that explain recourse to force in actual encounters [15]. Dispositional explanations can be divided into those emphasising personality and those that give more weight to culture. Toch [16] is perhaps the most eloquent exponent of the view that personality is the main influence on behaviour, echoed in the Christopher Commission [17] whose report on the Los Angeles Police drew attention to the small proportion of officers whose profile of use of force and complaints regarding their behaviour suggested they were aberrant (see also [18, 19]). It was concern that officers with a propensity to violence might be recruited in specialist armed squads in Britain that promoted the use of psychometric testing ([20, 21], see also [22]). Whilst most personality differences are fairly randomly distributed in the population, gender differences are not. There is considerable dispute about whether and to what extent female officers are as prone to using force as their male colleagues: some research claims that women officers are markedly less likely to use force [23-25] whereas other studies indicate little or no difference exists [26-29].

Such personality based arguments have their critics, as Adams points out:

It is probably true that a small number of officers are involved disproportionately in use of force incidents, but it may also be true that this is a statistical artefact and that with time their pattern regresses to the mean (contra the Christopher Commission) [30].

Moreover, it is difficult to imagine that the disparities in rates of police shootings and killings across different jurisdictions (including those represented in this research) could conceivably be due to vastly higher concentrations of 'violenceprone officers' in some jurisdictions rather than in others.

Cultural explanations share the underlying dispositional assumptions of Toch's 'violence-prone officers', but attribute it to a different source - the culture either of the society in which they work or, more specifically, the culture of the police. General societal explanations have been used to explain differences in police forcefulness over time [31]; between regions of the US [32]; varying social circumstances, such as society-wide stress [33]; and between different countries [34, 35]. More common are explanations that emphasise the specific influence of the police culture, especially its glorification of violence $[4,5,36]$. Specialist squads are 
thought to be particularly prone to developing a violent sub-culture [37], but this is not supported by other evidence [38].

A specific and particularly relevant version of dispositional explanations is that which explains differential levels of use of force by police against ethnic minorities. This leads to the conclusion that racism (whether a product of personality or culture) may reach all the way to the trigger finger [39-47].

Situational theories of police use of force look not towards the dispositions of officers in explaining why they act coercively or otherwise, but towards the circumstances in which they act. This, of course, evokes a longstanding debate in social psychology between personality and situational explanations of human behaviour generally [48, 49]. In respect of policing, situational explanations also divide into two: those that consider the immediate situation and those that stress the wider circumstances. Features of the immediate situation that might precipitate a forceful police response include such factors as the offence for which a person is suspected [50]; degree of resistance shown by suspects [51]; the number of police officers present at the scene [52]; and much else besides [53].

Whilst immediate situational factors explain a great deal of the variance between the use of force by officers within cities in America, it leaves unexplained the variance between cities. Skolnick and Fyfe [36] describe how police departments can autonomously adopt aggressive policing policies that result in hugely disproportionate levels of police use of force. Even in the absence of such distinctive policies, cities can vary significantly. This was the focus of Liska's [54] research: he found that background factors, such as the proportion of non-white people living in cities, the degree of segregation between racial groups, general homicide rate and size of the police force were correlated with differences in the use of lethal force by police officers [55]. He hypothesised that the more sizeable the non-white population the greater was the threat to the interests of the white majority, which police action focused on controlling threat by repressive means.

Of course, in our research the scenario was hypothetical and we can adduce no evidence that it reflected the actual behaviour of any of the officers involved in our focus groups, and certainly we can make no judgement of how widely focus group discussions represented the voices of others. Nevertheless, our evidence suggests that the distinction between dispositional and situational theories of police use of force is unhelpful. On the one hand, it might be said that the results of our focus groups are more consistent with situational rather than dispositional theories. Focus groups displayed little divergence in terms of their adherence to the general principles that lethal force was only justified by an immediate and credible threat to life and that the interests of innocent bystanders were paramount. Neither was there much difference between them regarding official policies and the likelihood that the use of lethal force would be followed by intrusive examination of the justification for their actions. In short, they shared common values and knowledge that might be expected to restrain them in the use of force. What distinguished the European and Australian focus groups from those convened in Latin America was their perception of threat [54]. That perception is clearly justified for levels of crime and violence are far higher in Latin America than in Europe and Australia [56]. This was reflected in the focus group discussions: in Europe and Australia, the use of guns was regarded (even in jurisdictions whose police are armed) as exceptional. By contrast, in Latin 
America it was perceived as quite likely that suspects would be armed, and might even be in possession of grenades, and they would show little hesitation in using those weapons! Hence, officers anticipated that the normative requirements for opening fire were likely to be met. Accordingly, they envisaged taking precautions, such as not approaching the suspect vehicle and unholstering their firearms at an early stage.

On the other hand, our data clearly demonstrates that risk is a perception. Our focus groups were considering an explicitly hypothetical situation to which they brought their beliefs, expectations and anxieties. The environment in which Latin American police work clearly parallels the conditions that Liska and Yu identify as threatening in American cities: large ethnic minority population, residential segregation, high levels of homicide and deprivation [55]. Of course, in Latin America there are also differences: first, in Venezuela, there has been much racial/ ethnic intermixing and thus one cannot say that the barrios hold a large ethnic minority population. Secondly, in Brazil, skin colour remains as an important quasiracial classifying criterion, but the "blacks" in Brazil are not really considered to be ethnically separate, just socially and culturally inferior. However, on the face of it, these appear to be external, objective facts about the environment that are linked to variations in police use of lethal force.

Yet, these variables are not simply stark facts to which people are condemned to react, they are mediated through interactions between individuals, even if those interactions can become lethally confrontational, as Liska and Yu observe:

Most police homicides occur when police interrupt a robbery or burglary in progress or intervene in a social disturbance, including family quarrels, fights, and assaults. Because of cultural beliefs linking nonwhites to street violence and crime, police may feel particularly threatened in neighborhoods and cities where the percentage of nonwhites is relatively high. [55: 68. Italics added]

As Liska and $\mathrm{Yu}$ also concede in this passage, the background variables are also mediated through 'cultural beliefs.' The fact that people-police officers or anyone else-believe things, does not mean that those beliefs are untrue. Indeed, Liska and Yu's own analysis implies that police officers are aware of the relative size of the non-white population and prevalence of homicide. However, it is certainly also true that people may hold erroneous beliefs: believing things that are untrue and failing or refusing to recognise the truth. Belief, perception, cognition, and so forth, are crucial mediating factors between social conditions and action. This is particularly so with respect to threat: for threat is a complex cognitive operation that entails not only an intuitive calculation of the past (the proportion of adverse outcomes to the total number of outcomes), but also a projection into the future (what will others in a particular situation actually do?). Moreover, these calculations may need to be made with respect to diverse others. Contemplating using lethal force involves not only assessing the risk of being fired upon by an adversary, but also the risk of causing harm to bystanders, and the likelihood of future investigation. Sometimes it extends to the 'moral hazard' of allowing 'scumbags' to be disrespectful of police authority.

This is precisely the territory over which our focus groups were invited to navigate. They were not asked about whether they agreed with general principles or norms, but were presented with an unfolding specific scenario. Whilst hypothetical, it was universally regarded as credible, especially during its initial stages. Focus 
groups had the opportunity, not afforded to police officers in actual situations, to reflect upon and discuss what would be appropriate actions in those circumstances. By these means the participants made explicit the beliefs, perceptions and cognitions that they bring to any such encounter.

\section{Culture}

We have been cautious so far in referring only to how officers talk about force, but whilst actual behaviour in a situation cannot be inferred directly from how officers talk about it, that does not mean that talk is irrelevant to action. If it did, precious little criminology would be relevant to explaining how people act, because it is rare to witness directly deviant behaviour and virtually impossible to do so under anything remotely resembling controlled conditions.

This raises the issue of culture, especially police culture, and its role in mediating experience and moulding a sense of ecological threat. Three features of our focus group discussions are notable in this context: first, that our scenario evoked considerable and at times intense discussion. So often, police culture is treated as though it is a monolithic set of rules and recipes for action, but in our focus groups, when faced with a scenario that at least begins as a routine encounter, officers argued and disagreed about the best course of action. The overview given here of those discussions hardly does justice the extent of such debate. For example, in England there was a profound disagreement between focus groups composed of armed officers, on the one hand, and unarmed officers, on the other. This suggests that instead of conceptualising culture as a set of relatively uncontested directives, it may be better conceived as ways of imagining what circumstances might be like and how variously to respond to them. Shearing and Ericson ([57], see also [58]) have proposed that culture generally, and police culture in particular, is conveyed mainly through story-telling containing tropes that are readily recognised. Officers bring to the canteen or other backstage areas [59], their experiences that they relate usually as narratives. In the collective 'repair shop' where anecdotes are exchanged [60], salient features are identified and alternative courses of action are recommended (for example, see [61] for an analysis of the divergent ways in which RUC officers coped with the threat of terrorist violence).

Our scenario methodology fits very well with this conceptualisation of police culture, for it too consisted of a story (albeit conjured by academic researchers rather than the officers in our focus groups themselves) and, at least in its initial stages, was readily recognisable. For instance, the brief sketch of the occupants of the car was sufficient to evoke a richly textured understanding of what such a person was like and how they were likely to react. Although officers differed about how the suspects should be dealt with - for instance, some Dutch officers felt that it was better to talk to the occupants of the car despite the latter's abuse, whereas others would have been more forceful ("My way or the highway"!) - there was implicit agreement that officers must retain control of the situation, including themselves. When the car was described as speeding off, this was widely regarded as evidence of incompetence.

Secondly, insofar as the participants in our focus groups were expressing cultural assumptions and stereotypes, it was a very far cry from how police culture is often conceptualised in academic analysis (see [6] for a general discussion). Yes, officers 
did feel the tension between their 'hunting instinct' and the constraints of official rules that they almost universally regarded with disdain. However, the overwhelming sense of caution that was voiced by all sits oddly on the lips of officers whose culture is renowned for its machismo [62]. In Europe and Australia officers exhibited restraint, even when considering a scenario that invited forceful intervention and since it was hypothetical it involved no real consequences. If this was just talk, then why not open fire on an escaping youth apparently armed with a gun, who has led officers on a perilous chase and collided with an innocent bystanders' vehicle? Isn't that what 'Dirty Harry' would do? [63] But our focus groups were not composed of 'Dirty Harry' wannabes. Their attention was focused on the legal and normative justification for using force, and in all cases on the danger to bystanders. Perhaps this is most acutely evident in England, for the focus groups composed of armed officers might be expected to represent the most macho variant of police culture. These officers form an elite who specialise in the use of lethal force, and yet it was they who repeatedly exhibited the most caution. "What have we got?" they repeatedly asked, and the answer that they gave was that the situation did not warrant the use of lethal weapons.

Thirdly, this research is a distinct, if not unique, exercise in cross-cultural comparison. Police cultures are most often analysed in isolation; occasionally, comparisons are drawn between police and other sections of the population (although the extent to which this can be consider 'cultural' is doubtful since it usually relies on the methodological individualism of questionnaires and attitude scales); sometimes, police from different jurisdictions within a society are compared; but to compare police in different countries as we have done is rare (Klockars et al. [64] are an honourable exception). Yet, it is only by making comparisons across diverse cultural contexts that it is possible to draw conclusions about the extent to which police culture is universal or reflects the peculiarities of its wider cultural context. For instance, Chan's sophisticated research on policing in New South Wales $[34,65]$ concludes that cultural change is inhibited by the colonial origins of Australian society and its policing structures. Yet, focus groups in the neighbouring Australian state of Victoria did not exhibit the differences that such a heritage suggests. Neither is there a detectable gulf between police in England, the Netherlands and Germany. Not only is the Channel culturally bridged, but so too is the globe. Yet, there is a difference between these otherwise diverse countries and those of Venezuela and Brazil. Our explanation for these differences lies in how officers in different social circumstances perceive threat. However, threat not only lies in the barrel of a gun that is pointed at an officer, it also lies in the extraordinary exemption that is given to police to use force, possibly lethal force. All our focus groups exhibited a clear realisation of how exceptional were the powers and responsibilities that they exercised. We tentatively suggest that this is a commonality of police culture-it is cautious, because officers believe they are surrounded by threats.

\section{Conclusions}

This research consisted of focus groups in six diverse countries discussing a nearidentical scenario. This elicited richly textured discussion and debate amongst the 
officers who participated. Our over-arching analysis of that debate concludes that there are remarkable continuities across focus groups. They agree that the scenario is a routine encounter, yet one that poses risks that need to be managed by a combination of firmness and tact. Once the suspect car drives off, officers feel the tension between the imperative to follow their 'hunting instinct' and the restraints of official policies that preclude car chases. It is in the final stage of the scenario that clear differences emerge between European and Australian focus groups who are wary of provoking a potentially armed confrontation, on the one hand, and, on the other, Latin American focus groups, who regard such a confrontation as inevitable. We suggest that this is explicable as different cultural appraisals of the level of threat posed in policing marginal populations in these different social and physical environments.

\section{References}

1. Adams, K. (1996). Measuring the prevalence of police abuse of force. In W. A. Geller, \& H. Toch (Eds.), Police violence: Understanding and controlling police abuse of force (pp. 52-93). New Haven: Yale University Press.

2. Adams, K. (1999). What we know about police use of force. Report to the National Institute of Justice: Use of force by police: Overview of national and local data. Washington, DC: US Department of Justice.

3. Travis, J., Chaiken, J. M., \& Kaminski, R. J. (1999). Use of force by police: Overview of national and local data. Washington, DC.: National Institute of Justice and Bureau of Justice Statistics.

4. Chevigny, P. (1995). Edge of the knife: Police violence in the Americas (p. 319). New York: New Press.

5. Terrill, W., Paoline, E. A., \& Manning, P. K. (2003). Police culture and coercion. Criminology, 41(4), 1003-1034.

6. Reiner, R. (2000). The politics of the police (p. 279, 3rd ed.). Oxford: Oxford University Press.

7. O'Connor, D. (2005). Closing the gap: a review of the 'fitness for purpose' of the current structure of policing in England \& Wales. London: HM Inspectorate of Constabulary.

8. Hough, M. (2007). Policing London, 20 years on. In A. Henry, \& D. J. Smith (Eds.), Transformations of policing (pp. 191-212). Aldershot: Ashgate.

9. Blakey, D., \& Crompton, D. (2000). 'Winning Consent': A review of murder investigation and community and race relations issues in the metropolitan police service. London: Her Majesty's Inspector of Constabulary.

10. McLaughlin, E. (2006). The new policing. London: Sage.

11. Waddington, P. A. J., \& Wright, M. (2008). Police use of force, firearms and riot-control. In T. Newburn (Ed.), Handbook of policing. Willan: Collumpton.

12. Rico, J. M. (1997). Justicia Penal y Transición Democrática en América Latina. Mexico: Siglo XXI.

13. Gabaldón, L., \& C. Birkbeck (Eds.) (2003). Policía y Fuerza Física en Perspectiva Intercultural. Nueva Sociedad: Caracas.

14. Briceño-León, R. et al. (2002). Tiene la Policía Derecho a Matar a los Delincuentes? Un Estudio de Apoyo Ciudadano a la Violencia Policial. In R. Briceño-León and R. Pérez-Perdomo (Eds.), Morir en Caracas (p. 179-192). Caracas: Universidad Central de Venezuela.

15. Terrill, W., \& Mastrofski, S. D. (2002). Situational and officer-based determinants of police coercion. Justice Quarterly, 19(2), 215-248.

16. Toch, H. (1996). The violence-prone officer. In W. A. Geller, \& H. Toch (Eds.), Police violence: Understanding and controlling police abuse of force (pp. 94-112). New Haven: Yale University Press.

17. Christopher, W. C. (1991). Report of the Independent Commission on the Los Angeles Police Department. Los Angeles.

18. Lester, D. (1996). Officer attitudes toward police use of force. In W. A. Geller, \& H. Torch (Eds.), Police violence: Understanding and controlling police abuse of force (pp. 180-190). New Haven: Yale University Press. 
19. Grant, J. D., \& Grant, J. (1996). Officer selection and the prevention of abuse of force. In W. A. Geller, \& H. Toch (Eds.), Police violence: Understanding and controlling police abuse of force (pp. 150-164). New Haven: Yale University Press.

20. Shepherd, E., \& Walsh, T. (1986). Selection and training of authorised firearms officers, Report on a pilot study. City of London: Applied Psychology Unit.

21. Mirrlees-Black, C. (1992). Using psychometric personality tests in the selection of firearms officers. Research and Planning Unit Papers. London: H.M.S.O.

22. Shepherd, E., \& Walsh, T. (1987) Identifying the 'at risk' armed officer.

23. Jones, S. (1986). Policewomen and equality: Formal police v informal practice? (p. 235). London: Macmillan.

24. Braithwaite, H., \& Brewer, N. (1998). Differences in the conflict resolution tactics of male and female police patrol officers. International Journal of Police Science and Management, 1(3), 276-287.

25. Shockley-Zalabak, P. (1984). Sex differences in conflict style preferences. Communications Research Reports, 1, 28-32.

26. Bloch, P. B., \& Anderson, D. (1974). Policewomen on patrol: Final report. Washington, DC: Police Foundation.

27. Ffrench, M., \& Waugh, L. (1998). The weaker sex? Women and police work. International Journal of Police Science and Management, 1(3), 260-275.

28. Sherman, L. W. (1975). An evaluation of policewomen on patrol in a suburban police department. Journal of Police Science and Administration, 3, 434-438.

29. Grennan, S. A. (1987). Findings on the role of officer gender in violent encounters with citizens. Journal of Police Science and Administration, 15, 78-85.

30. Adams, K. (1999). What we know about police use of force. In J. Travis, J.M. Chaiken, \& R.J. Kaminski (Eds.), Use of force by police: Overview of national and local data (pp. 1-14). Washington, DC.: National Institute of Justice and Bureau of Justice Statistics.

31. Walker, S. (1977). A critical history of police reform: The emergence of professionalization. Lexington: Lexington.

32. Milton, C. H., et al. (1977). Police use of deadly force. Washington, D.C.: Police Foundation.

33. Jakubs, D. L. (1977). Police violence in times of political tension: The case of Brazil, 1968-71. In D. H. Bayley (Ed.), Police and Society (pp. 85-106). Beverly Hills: Sage.

34. Chan, J. B. L. (1997). Changing police culture: Policing in a multicultural society (p. 255). Cambridge: Cambridge University Press.

35. Berkeley, G. E. (1969). The democratic policeman. Boston: Beacon.

36. Skolnick, J. H., \& Fyfe, J. J. (1993). Above the law: Police and the excessive use of force (p. 313). New York: Free Press.

37. Kraska, P. B., \& Kappeler, V. E. (1997). Militarizing American police: The rise and normalization of paramilitary units. Social Problems, 44(1), 1-18.

38. Williams, J. J., \& Westall, D. (2003). SWAT and non-SWAT police officers and the use of force. Journal of Criminal Justice, 31(5), 469-474.

39. Locke, H. G. (1996). The color of law and the issue of color: race and the abuse of police power. In W. A. Geller, \& H. Toch (Eds.), Police violence: Understanding and controlling police abuse of force (pp. 129-149). New Haven: Yale University Press.

40. Geller, W., \& Karales, K. (1981). Split second decisions: Shootings of and by Chicago Police. Chicago: Chicago Law Enforcement Study Group.

41. Geller, W. A., \& Toch, H. (1996). Police violence: Understanding and controlling police abuse of force (p. 379). New Haven: Yale University Press.

42. Matulia, K. (1981). Justifiable homicide by the police: A study of homicide by the police in 57 US cities. Gaithersburg: International Association of Chiefs of Police.

43. Friedrich, R. J. (1980). Police use of force: individuals, situations and organizations. Annals of the American Academy of Political and Social Science, 452, 82-97.

44. Kobler, A. L. (1975). Figures (and perhaps some facts) on police killings of civilians in the United States, 1965-1969. Journal of Social Issues, 31(1), 185-191.

45. Meyer, M. W. (1980). Police shootings at minorities: the case of Los Angeles. Annals of the American Academy of Political and Social Science, 452, 98-110.

46. Fyfe, J. J. (1982). Race and extreme police-citizen violence. In J. J. Fyfe (Ed.), Readings on police use of deadly force (pp. 173-194). Washington: Police Foundation.

47. Mendez, G.A. (1983). The role of race and ethnicity in the incidence of police use of deadly force (p. 114-115). In Anon. (Ed.), Annual report. New York: National Urban League. 
48. Brim, O. (1960). Personality development as role learning. In I. Iscoe, \& H. Stevenson (Eds.), Personality development in children (pp. 127-159). Austin: Texas University Press.

49. Mischel, W. (1973). Toward a cognitive social learning reconceptualization of personality. Psychological Review, 80, 252-283.

50. Sherman, L. W. (1980). Causes of police behaviour: the current state of quantitative research. Journal of Research in Crime and Delinquency, 17, 69-99.

51. Alpert, G. P., \& Dunham, R. G. (2004). Understanding police use of force: Officers, suspects, and reciprocity (p. 191). Cambridge: Cambridge University Press.

52. Worden, R. E. (1996). The causes of police brutality: theory and evidence on police use of force. In W. A. Geller, \& H. Toch (Eds.), Police violence: Understanding and controlling police abuse of force (pp. 23-51). New Haven: Yale University Press.

53. Bayley, D. H., \& Garofalo, J. (1989). The management of violence by police patrol officers. Criminology, 27(1), 1-23.

54. Liska, A. J. (1992). Social threat and social control (p. 240). Albany: State University of New York.

55. Liska, A. E., \& Yu, J. (1992). Specifying and testing the threat hypothesis: Police use of deadly force. In A. J. Liska (Ed.), Social threat and social control (pp. 53-68). Albany: State University of New York.

56. United Nations (1999). Global report on crime and justice. New York: Oxford University Press.

57. Shearing, C. D., \& Ericson, R. V. (1991). Culture as figurative action. British Journal of Sociology, 42 (4), 481-506.

58. Ericson, R. V. (2007). Rules in policing: Five perspectives. Theoretical Criminology, 11(3), 367-402.

59. Holdaway, S. (1983). Inside the British police. Oxford: Blackwell.

60. Waddington, P. A. J. (1999). Police (canteen) sub-culture: An appreciation. British Journal of Criminology, 39(2), 286-308.

61. Brewer, J. D. (1990). Talking about danger: the RUC and the paramilitary threat. Sociology, 24(4), 657-674.

62. Fielding, N. (1994). Cop canteen culture. In T. Newburn, \& E. Stanko (Eds.), Just boys doing business: Men, masculinity and crime (pp. 46-63). London: Routledge.

63. Klockars, C. B. (1980). The dirty Harry problem. Annals of the American Academy of Political and Social Science, 452, 33-47.

64. Klockars, C. B., Kutnjak Ivkovich, S., \& Haberfeld, M. R. (2004). The contours of police integrity (p. 305). Thousand Oaks: Sage.

65. Chan, J. B. L. (2003). Fair cop: Learning the art of policing. Toronto: University of Toronto Press. 